\title{
"Schoolchildren would not now be protesting had Greta Thunberg not made her stand. Writers have begun to take note". An Interview with Celia de Fréine
}

\author{
Manuela Palacios-González \\ Universidade de Santiago de Compostela, Spain \\ Luz Mar González-Arias \\ Universidad de Oviedo, Spain
}

Copyright (c) 2020 by Manuela Palacios-González and Luz Mar González-Arias. This text may be archived and redistributed both in electronic form and in hard copy, provided that the authors and journal are properly cited and no fee is charged for access.

\begin{abstract}
In this interview with Celia de Fréine, the Irish writer discusses her prolific and varied literary production in a wide range of genres, with a special focus on current ecological concerns and their impact on creative writing. This ecological interest is finding its way in a literary system, the Irish one, in which debates around national borders and women's place in the nation are far from resolved. Besides biological diversity, the writer discusses cultural and linguistic diversity, especially in relation with the present-day situation of the Irish language, the role of translation and its effect on the reception of the writer's work, the permitted themes past and present, the subtle ties between language, setting and theme, and other subjects pertinent to language choice. Among other significant ecological concerns, Celia de Fréine appraises the following: the growingly blurring boundary between rural and urban spaces due to urban sprawl, the ailments of the social and human body, the interconnections between human and non-human bodies, the celebration of well preserved and inspiring natural environments, and the associations of landscapes with particular literary traditions from Ireland and beyond. The interview ends with a reflection upon the impact of the Covid-19 pandemic on creative writing.
\end{abstract}

Keywords. Celia de Fréine, Irish literature, Irish language, Translation, Ecology, Landscape, Body, Covid-19.

Resumen. En esta entrevista con Celia de Fréine, la escritora irlandesa nos habla de su prolífica producción literaria en diversidad de géneros, con especial atención a los problemas ecológicos y su impacto en la creación literaria. Esta preocupación ecológica se abre paso en un sistema literario, el irlandés, en el que los debates sobre la frontera y el lugar de las mujeres en la nación no están aún resueltos. Además de en la diversidad biológica, la escritora indaga en la diversidad cultural y lingüística, en la situación actual de la lengua irlandesa, el papel de la traducción y su efecto en la recepción literaria, los temas consentidos pasados y presentes, los 
sutiles vínculos entre lenguaje, localización y tema, y otros asuntos relativos a la elección de la lengua. Entre otras cuestiones de relevancia ecológica, Celia de Fréine valora las siguientes: la creciente imprecisión de la frontera entre lo rural y lo urbano debido a la expansión de las ciudades, las dolencias del cuerpo social y el cuerpo humano, las interconexiones entre la corporeidad humana y no humana, la celebración de los espacios naturales bien conservados y las asociaciones de ciertos paisajes con tradiciones literarias concretas tanto dentro como fuera de Irlanda. La entrevista finaliza con una reflexión sobre el impacto de la pandemia Covid-19 en la creación literaria.

Palabras clave. Celia de Fréine, literatura irlandesa, lengua irlandesa, traducción, ecología, paisaje, cuerpo, Covid-19.

Celia de Fréine is an inhabitant of liminal spaces. Born in Co. Down, Northern Ireland, she has been based in Dublin most of her life and now divides her time between Dublin and Connemara. Her being betwixt and between extends to her creative activity - as she has written poetry, plays, short fiction, memoir and non-fiction, opera libretti, and scripts for film and television and to her constant crossings of the language divide in Ireland, writing both in Irish and in English. Her influences are also multiple - Irish-language myths and legends, English canonical literature, Eastern European poetic forms, the Mediterranean and Atlantic coasts, to mention but a few. For many writers there exist favourite themes, preferred areas of exploration that they revisit over and over; for others, their creative activity is directed by changing forces that take them to both familiar landscapes and unexplored new territories alike. De Fréine definitely belongs to the latter group.

Her career is productive and extraordinarily rich and varied, as each of her nine collections of poetry, and each of her numerous produced plays is different from the previous ones. She has touched upon immigration, gender, national identities, illness, medicine, physical decay and death, sex, war, and the literary canon, contributing to the most heated debates on Irish history and contemporary society, and often being ahead of her time. Her work has been widely anthologized and has received national and international awards, such as the Best Screenplay Award in the New York International Film Festival (for Marathon); the Gradam Litríochta Chló Iar-Chonnachta for Fiacha Fola (Blood Debts), her poetic articulation of the so-called Hepatitis C scandal in Ireland; the Patrick Kavanagh Award; and the British Comparative Literature Association Translation Award, among them.

We are immersed in the Era of the Anthropocene. In spite of scientific evidence on the existing and potential threats to the ecosystems and biodiversity of our planet, and warnings of the fatal consequences of plastic and other toxic agents on human and non-human life, our world is facing an ecological crisis of incalculable dimensions. In the interview that follows, De Fréine focuses on such debates and on how the animal world - both human and non-human - and the landscapes of her life - both urban and rural, real and imaginary - have impinged on her creative career. ${ }^{1}$

I bhFreagairt ar Rilke: In response to Rilke (Arlen House 2020) is the title of Celia de Fréine's most recent poetry collection. For detailed information on her oeuvre, please visit her website www.celiadefreine.com

Manuela Palacios: Celia, you have written part of your work in Irish, part in English and some of your books of poetry and drama are published in bilingual editions with your own translations. When we talk of ecology and biodiversity, we also need to take into consideration cultural diversity and the concomitant support to the minority languages 
and cultures that enrich our lives. What is the situation of the Irish language now in Ireland and what are the challenges that Irish-language writers must face at present?

Celia de Fréine: According to the 2011 census (Wade), 77,185 people out of a population of approximately 4.6 million speak Irish in Ireland every day -fewer than those speaking Polish. As these figures suggest, the market for Irish-language readers and theatre-goers is small. Translation into English of Irish-language writing, once frowned upon as yielding to the "might" of a global language, is now accepted as an essential vehicle through which Irishlanguage writing can be brought to a wider audience both in Ireland and abroad. My first two books of poetry (Faoi Chabáistí is Ríonacha, Fiacha Fola), written in Irish, were published as a result of winning awards in an Irish language competition. These were followed by three bilingual books (imram: odyssey, Aibitir Aoise: Alphabet of an Age, cuir amach seo dom: riddle me this). I've also written two books in English (Scarecrows at Newtownards; A Lesson in Can't) and a third which is a translation of one of the first two (Blood Debts). My most recent poetry collection I bhFreagairt ar Rilke: In response to Rilke is also bilingual. I have translated plays at the request of others - publishers and readers - or, at times, when it was simpler to have a play produced in English rather than in Irish.

Today there is a greater acceptance of women's writing in Irish, which can in part be attributed to the growth in the number of women academics, critics, editors and judges of literary competitions. I have recently been commissioned to write a novel, the subject of which would have been unacceptable thirty years ago. This brings me to the area of influence on work in Irish: when I first began to write poetry in 1992, acceptable influences tended to be rural, folkloric and those that harped back to days of poverty and deprivation. Global influences are without question at play in present-day Irish-language writing, in particular in the work of younger poets who speak without reservation of their lifestyles and the challenges faced by them.

Advantages to writing in Irish include many bursaries, commissions and competitions. The act of writing in Irish itself has become simpler with the advent of up-to-date online dictionaries.

Luz Mar González-Arias: You move smoothly between the English language and the Irish language, both in your everyday life and in your creative work. I am wondering if certain landscapes take you to a certain language and vice versa. Does the West of Ireland speak in Irish to you as opposed to a Dublin urban setting? Or, on the contrary, does language choice come from a totally different, unconscious place?

CdF: Irish is better suited to the surreal than English. As some of my poems have a surreal setting, and some of my plays belong to the Theatre of the Absurd, these work better in Irish. The poetry I write in English is poetry that must be written in English: A Lesson in Can't concerned an English variety influenced by Cant, the Traveller language, and quite a few of the poems in Scarecrows at Newtownards are written in the voice of Shakespeare's women and in forms, such as the sonnet and sestina, which we have come to associate with English. My four bilingual books, inspired in most part by time spent in Europe, written in response to different languages and exciting landscapes, could only have been written in Irish. However, I have produced two sequences of poems in English during time spent in America. One is in response to the artwork of Mark Gerald McKee (Thresholds), a second, Lost in Shadow, is forthcoming. These were written in English as I was surrounded by the English language and the landscape, though new, was familiar from watching films and television shows set in America.

As far as my plays are concerned, some of these, written in Irish, have been translated to English to meet a certain need. Both Cruachás and Meanmarc were translated at the behest of my publisher. Slán [Safe] was translated as it was too much of a challenge to have it produced

Estudios Irlandeses, Special Issue 15.2, 2020, pp.102-116. ISSN 1699-311X. Manuela Palacios-González and Luz Mar González-Arias. 
in Irish. More recently I have translated "Casadh" for the same reason. "Casadh", which was commissioned by the Abbey Theatre as part of the Gach Áit Eile series in 2009, has been retitled "On the Bull Wall" and featured in Umbrella Theatre Company's show Eight of Hearts.

LMGA: Your position as an "in-between" writer - who crosses, among others, the language divide - has been, as you have just mentioned, a great influence on your thematic choices. However, I wonder if it has also played a part in the reception of your work. Poetry is particularly apt for the dissident, the different, but does a bilingual language choice affect the poet and his/her place in a given poetic tradition? Does it also affect what each of the two linguistic traditions expects from you?

CdF: There is always a question mark over the acceptance of the writer who has a foot in both language camps, certainly in Ireland. Establishing a readership in either language can be a challenge. Though I am well-known in English-writing circles, not many English language writers are familiar with my work in Irish. In Irish language circles not many are familiar with my work in English.

Translation - i.e., movement between languages - is now becoming recognised as both a skill and an art form. Public debates and conversations on translation are becoming more frequent. The debate on whether pride of place should be given to an accurate translation or an artistic one is ongoing. Personally, I like translations to be both accurate and artistic.

I write poems first in Irish and then translate them to English. The act of translation is in itself a good editorial tool in that, through it, I can weed out anything that is superfluous or over-written. Through working on both texts simultaneously, I hone the poem in both languages, making sure it works in both.

LMGA: Many of the ecological messages of our time are coming from the arts: poets and visual artists alike are creating elegies against the disappearance of our planet's flora and fauna. In general, contemporary poetry is not inspired by Arcadias, but rather by the darkness associated to the Anthropocene, i.e., the damage caused to the planet. Would you consider that this consciousness has superseded previous historical preoccupations of Irish literature such as nationalism and feminism? Has it affected your own work?

CdF: I feel that poetry inspired by ecological disaster is only gradually making its presence felt in Ireland. Our natural response to it may have been thrown out of kilter by preoccupations with nationalism and feminism caused as a result of recent historical commemorations. Much was written as part of the celebrations marking the centenary of the 1916 Rising and the election of Constance Markievicz to the Parliament of Westminster in 1918, the year in which some women gained the right to vote in Ireland and England.

As with Fiacha Fola, when it came to Markievicz, I was ahead of my time in that I had had plays about her produced in the late eighties. I didn't have the stomach to take them out again and dust them off. I did, however, write and direct a play, Luíse, based on the early life of Louise Gavan Duffy who cofounded Scoil Bhríde, our local school, the first gaelscoil in Ireland. Gavan Duffy also spent Easter Week 1916 in the General Post Office, the Headquarters of the Rising. Luíse was followed by Ceannródaí my biography of Gavan Duffy. Both play and biography tick the nationalism and feminism boxes.

It is worth mentioning also the wave of Northern Irish writers, many of whom are women, whose work is coming on stream twenty one years after the signing of the Good Friday Agreement. Anna Burns, Wendy Erskine and Jan Carson, to name but a few of these exceptional writers, are making a huge impression on Irish Literature at the moment. While the focus of their work may not be nationalist, it is certainly feminist, and political, not least in that it is written by writers who lived during the Troubles, often the setting for their work. 
In addition to such writing, memoir writing and work on the theme of migration and the challenges faced by migrants are popular in Ireland at present. As it happens, two plays on the theme of migration, which I wrote some time ago, are being read and studied now. "Na Deoraithe", published in the collection Blúiriní, is a recommended Junior Certificate text and has been republished in six textbooks. "Tearmann", published in Mná Dána, is being studied in university.

It is difficult to know whether, as writers, we should set out to focus on ecological matters or whether we should allow our focus to evolve naturally. Certainly, this interview makes me question what I should write next. Schoolchildren would not now be protesting had Greta Thunberg not made her stand. Writers have begun to take note.

MP: What are the main changes you have noticed in Irish landscape since you started writing? Are you conscious of the way in which these changes may have affected your writing? Is it possible for a contemporary writer to find inspiration in nature in spite of current environmental problems?

CdF: The Irish landscape has changed dramatically in that, with the advent of motorways crisscrossing the country, travel is more straightforward and less time consuming. In the past it may have been picturesque to travel through grassy plains and quaint villages but it seemed to take forever to get from Dublin to Galway, a journey I undertake regularly. Now it is possible to reach Galway in half the time which means I appreciate the countryside all the more when the motorway ends, the winding road to Connemara begins and I catch my first glimpse of the Atlantic. There have been major changes within these cities: apartment blocks continue to shoot up in vacant lots; the answer to traffic congestion in Dublin seems to be to cut down trees to make room for more cars and buses.

When I began to write poetry I was described as an urban poet. However, my first book Faoi Chabáistí is Ríonacha comprises poems with both urban and rural settings. At the time, I was writing plays which belonged in the Theatre of the Absurd. Many of the settings for the poems in this first book could be described as absurd also. My second book Fiacha Fola, which follows the female body on a journey through childbirth and illness, caused by Hepatitis $\mathrm{C}$, is set in the city. It deals also with the destruction of the urban landscape. However, the attack on the woman's body, in particular the spread of a rash, one of the symptoms of Hepatitis C, is paralleled with the growth of a Virginia creeper on the narrator's garden wall.

Rural settings feature, for the most part, in my first three bilingual books, written as a result of residencies abroad and of spending time on my son's farm in Sardinia. cuir amach seo dom: riddle me this celebrates the environment and includes descriptions of many animals. The central section "An Bhean Uasal is an tAonadharcach: The Lady and the Unicorn", while inspired by tapestries in the Musée de Cluny in Paris, has a rural setting. "Lorg: Quest" and "Seal: Sojourn", two poems in Aibítir Aoise: Alphabet of an Age are, however, set in an Irish rural landscape. Both have been made into film-poems and have successfully brought the Connemara landscape to the screen.

Not only has my poetry moved from an urban to a rural setting, that setting has become realistic rather than "absurd". This has occurred as a result of being based in different locations while undertaking the work in question rather than by changes in the landscape. Though environmental problems might be foreshadowed in the poems, in particular in cuir amach seo dom: riddle me this, I have tended to write about present circumstances rather than look to the future.

MP: It is most interesting to observe that in your poetry you make use of international literary forms such as the Polish "Alphabet book", and the Slovene "riddle". Apart from 


\section{their literary and formal qualities, do they at all suggest other possible relations with the natural world: land, waters, animals and humans?}

CdF: The fact that the Alphabet Book and the Riddle are traditional forms suggests they developed in pre-industrial times. A third form I make use of is the Imram, an Irish traditional form, which recounts a journey to another world and which has as its cousin the international Odyssey.

The Polish Alphabet Book, written in prose, which gives accounts of the famous and the not-so-famous, tells many stories. As the poems in Aibitir Aoise had as subject many characters both living and dead, the Polish Alphabet seemed a fitting structure is which to frame them.

I was commissioned to write the interdisciplinary sequence cuir amach seo dom: riddle me this during a residency in Slovenia. This sequence, which forms the title poem in the collection of the same name, is accompanied by a video of images on which the English translation has been superimposed. It gives a nod to the riddle, one of the Slovene literary forms which seemed an apt form in in which to explore the concept of Lake Cerknica, a Slovene lake which disappears from time to time, thereby writing about the environment and posing questions for which there are no clear answers. The subject matter meant also that I could personify the lake in question, having noted that personification seemed to feature in much of the local poetry.

While in Slovenia I also wanted to give an account of my experience. The Imram seemed apt - I had travelled to a new world in which I was faced with many challenges. As with its cousin, the Odyssey, the Imram invokes images of sea, rocks, strange lands and hybrid creatures. However, in the original form it is the great hero who sets out on his voyage while the woman stays at home waiting for him to return; in my account it is the woman who undertakes the journey.

At the time of writing, all three forms seemed to work both thematically and structurally.

LMGA: In the course of this interview you have discussed your own work as both rural and urban, as inscribing roads, lakes, seas. I would like to focus on the Atlantic Ocean now, which is a great presence in your life, but what is its influence on your creative work?

CdF: My relationship with the Atlantic Ocean began twenty one years ago when we had the good fortune to buy a house in Connemara. One of my early poems "Seal Dá Saol", a metaphor for moving between languages, is set on Trá an Dóilín, the beach near our house. However, what attracts me most to the Atlantic Ocean is that it borders the Gaeltacht, i.e., the part of the country in which Irish is the spoken language.

I'm not that aware of having written many poems set on the Atlantic seaboard but have set two larger works, in which the sea plays a major part, there.

The first is a play "Cóirín na dTonn", in which many scenes are set on the beach. The main character, Cóirín, has just buried her demanding manipulative mother and she intends living her life on her own terms from now on. However, she has an alter ego, Críonna, who keeps taunting her. Maidhc, a neighbour, had always expected Cóirín to marry him after her mother's death but she turns him down, not wanting to have anyone dependant on her anymore. However, she falls in love with "blow-in" Ré. Her happiness is shortlived when Ré becomes ill. Cóirín helps him die with dignity and as a result spends time in prison. When released, she rushes down to the beach where Maidhc awaits her.

I had no difficulty writing the dialogue, as spoken by native speakers of Irish in Connemara, for this play. Perhaps this is because of the time I spent writing the TG4 soap opera Ros na Rún. However, when it came to writing the thriller, Cur i gCéill, the second larger work also set in Connemara, I felt it strategic to create a protagonist who is a blow-in. Cass, a recentlywidowed psychologist, moves to the Gaeltacht and accepts a part-time job working for An 
Garda Síochána as a forensic psychologist.

The Atlantic plays a large part in this book, in that it is where Cass swims regularly and where the body of a family friend, which sets in motion her quest to discover whodunnit, is washed up. It is only in answer to your question that I realise that both Cóirín and Cass are women who set about re-inventing themselves after the death of a close relative. Cass achieves greater success in this than Cóirín, however.

LMGA: You spend part of the year in Sardinia. As a coastal person myself, I find a great difference between the Atlantic and Cantabrian coasts, where I am based, and the Mediterranean Sea, which is stunning but does not have the same creative or existential power for me. What would your perception of the Mediterranean be and how would it affect your themes?

CdF: The poetry I wrote in Sardinia is more influenced by the landscape than the sea. The poem "Boladh an Mhismín Fhiáin: The Scent of Wild Mint" is an obvious example. The Portuguese landscape, which is similar to that of Sardinia, inspired poems in the "Monsanto" sequence in cuir amach seo dom: riddle me this also. There are probably more "sea" poems in imram: odyssey, set in Slovenia, on the Mediterranean Coast. In geography class in school I was taught that the Mediterranean was a large pond. But I have noticed tidal movement in it! Possibly the only poem I have actually set in the Mediterranean is "Doth Suffer a Sea-Change", in part inspired by the plight of migrants who have drowned in its waters.

When I was a child, Dublin Bay was a huge disappointment in that the tide was often too far out to go for a swim and that the sand was, even then, polluted. However, I spent my childhood summers in Donaghadee, a town in Northern Ireland, where the sea played a major part in most people's lives. I swam most days; I attended shows on the pier performed by the Pierrots. During these years there was much talk of the sinking of the MV Princess Victoria (1953) and of how the Donaghadee RNLI lifeboat saved lives then and since. My father's family were living in the Coastguard Station at the time.

As a young adult I began to visit Dún Laoghaire in south County Dublin and continue to do so. I am attracted to it as both its pier and lifeboat are similar to those in Donaghadee. However, the greatest attraction for me is the local monument to the crew of the lifeboat who drowned in the harbour on Christmas Eve in 1895. My grandmother's brother, James Ryan, was one of these. In Present, the first ten-minute play I wrote, I imagine his pregnant girlfriend pleading with him to not answer the summons. Her character Beth reappears in two subsequent plays Seamstress and Beth.

LMGA: The human body is an inescapable presence in your poetry. Your collection Blood Debts, for example, is entirely devoted to the so-called Hepatitis $\mathrm{C}$ scandal in Ireland and to the psychological, emotional, sexual and social consequences of embodying illness. As a poet who started writing and publishing several decades ago, do you think Irish literature has changed in terms of its representation of women's bodies, especially in situations of illness, ageing, or non-normative bodies?

CdF: When I began writing poetry in earnest in 1992, I was already familiar with what was being published in both literary journals and individual collections. I regularly came across poems, written by men, in which the female body was objectified. Though few poems which represented women's bodies were being written by women, poets such as Mary O'Donnell, were writing, and continue to write, on this theme.

Fiacha Fola, published in 2004, was awarded Gradam Litríochta Chló Iar-Chonnacht, a competition judged by Máire Mhac an tSaoi. Mhac an tSaoi is one of the three pioneers - the other two are Seán Ó Riordáin and Máirtín Ó Direáin - who created contemporary poetry in the 
Irish language. Not only was her poetry revolutionary in its concept, its language and structure, the female body often appeared in her work. I was extremely fortunate in that she was the judge of this competition and that she understood the book, something which other judges and editors did not. Another competition which I won was Comórtas Filíochta Dhún Laoghaire Ráth an Dúin which was judged by Áine Ní Ghlinn, who has also written on the female body and who understood the poem I had submitted ("Ocras"). When it comes to representing women's bodies in literature, Mhac an tSaoi established the way forward and poets of my generation followed suit in paving the way for younger poets, such as Emily Cullen, Jessica Traynor, Annemarie Ní Churreáin and Doireann Ní Ghríofa.

The recently published Constellations by Sinéad Gleeson, a collection of essays which focus on illness and recovery, has not only been critically acclaimed, it has received as much, if not more, attention than a popular novel might have. Fiacha Fola, published fifteen years ago, and In Your Face by Lia Mills, a memoir of her diagnosis of and treatment for oral cancer, published twelve years ago, though both critically acclaimed, received much less attention at time of publication. More often today the timing of the publication of a book seems to play a crucial part in its reception. Memoirs, essay collections as memoir, and books on illness and recovery certainly form part of today's zeitgeist.

LMGA: A very interesting aspect of Blood Debts is the parallelism it establishes between the contamination of a woman's body and the destruction of natural environments and ecosystems in Ireland. Does illness help humans to be more aware of ecological damages? In other words, are we more empathic with other species once our own physical integrity is under attack?

CdF: It is difficult to know. School children have come to realise that they will inherit the damage done by previous generations to the environment and that this damage has to stop now. Their worldwide protests against politicians for their lack of respect for the environment was spear-headed by the previously mentioned Swedish teenager, Greta Thunberg. Her stance has no doubt had an influence on the swing to the "green" vote, in particular by those under 25, in recent local and European elections.

Another constant in our daily news bulletins in Ireland is the fallout from the recent cervical smear atrocity in which women have died and continue to die as a result of incorrect test results. The application of symphysiotomies to women in Ireland, without their knowledge or consent during a forty-year period up to the late eighties, is another appalling travesty that continues to be debated.

In Fiacha Fola I charted the destruction of the urban landscape wreaked by the greed of developers during the Celtic Tiger period. I'm not sure how much the fallout from illness makes humans more aware of ecological damage. Perhaps physical, ecological and urban damage are streams that occur side by side without the realisation that each impacts on the other. While it is difficult to ascertain whether they parallel each other or whether they converge, it is clear that all three are a constant in contemporary Irish life.

MP: Your collection A Lesson in Can't is very original in theme, as it deals with your work with a Travellers' community. In this book of prose poems you engage with a variety of issues such as corporeality and nomadism. Could we say that these poems interrogate conventional understandings of the sense of place in Irish literature and bring to light a variety of taboos about the human body, especially the female body?

$\mathrm{CdF}$ : These poems could indeed be said to interrogate conventional understandings of the sense of place in Irish literature. What does place mean for Irish Travellers? It could be the place they move to from the place they have been forced to leave, either because they are driven by the 
need to be out on the open road or as a result of being moved on by the authorities. In many ways the poems explore a people in transition. Their instinct to travel is being suppressed on two fronts: outside forces which forbid them to camp on the side of the road and their own need for better living conditions.

It is worth noting that statistics regarding longevity and a lowering of infant mortality rate have changed dramatically since Travellers became settled and moved into houses. Although nomadism may be part of their DNA, growing up in a housing estate dilutes this need in younger generations, while at the same time many families keep a horse or caravan in their garden.

As to taboos and the human body, I was working with teenage girls and young adult women many of whom were getting married or had recently married. Their awareness of what was happening to their bodies whether they were getting pregnant, or unable to get pregnant or, in one case, undergoing an ectopic pregnancy, was a primary concern of theirs. Many of those about to get married did not know the facts of life. Taboos being brought to light concerned the very act of talking about sex.

Sometimes, when a settled person writes about a Traveller, that Traveller is the subject of either an anthropological study or of a romanticised version of life on the open road. This book could in ways be seen as a bridge in which teacher and student connect with the different worlds in which each other lives and whose differences become apparent through everyday interaction as set out in the poems.

MP: In 1982, you undertook the creative translation (adaptation to play-form and direction of a stage production) of Brian Merriman's Cúirt an Mheán Oíche: The Midnight Court (De Fréine 2012), a poem from the late eighteenth century that brings together the medieval genres of the dream-poem and the debate. In this text women give open expression to their sexual desire and courageously resist patriarchal and Catholic attempts to suppress it. What is the response of a present-day audience to these women's straightforward talk of sexuality?

CdF: When I first heard of Cúirt an Mheán Oíche: The Midnight Court its theme appealed to me: a fairy court convened to give voice to a young maiden who cannot find a husband and to call to account the men of Ireland for their lack of sexual prowess.

When the Dublin Shakespeare Society were celebrating their seventy-fifth anniversary in 1982 I volunteered to translate, dramatize and direct Merriman's poem. I had never translated or directed anything before. Though my initial engagement with Cúirt an Mheán Oíche came about by accident, it is an accident that has had a lasting effect on me.

The fact that Merriman's characters openly discuss the sexual mores of the day suggests that this was normal among the Irish peasant class of the late eighteenth century. More than two hundred years later people enjoy Cúirt an Mheán Oíche for its bawdiness, albeit a bawdiness that manages to convey real challenges experienced by the women of the time. Descriptions of how these women dressed and the places in which they lived are a good indication of what life was like back then.

Sixty years ago, when the censor reigned supreme in Ireland, productions of Cúirt an Mheán Oíche and other risqué plays in Irish were performed regularly. This was at a time when a production of Tenessee William's The Rose Tatoo, in which an imaginary contraceptive fell to the floor, closed the Pike Theatre. In fact, it was only when Frank O'Connor translated Cúirt an Mheán Oíche into English that the poem was banned.

My play Meanmarc: Desire is set during the time immediately before Merriman wrote Cúirt an Mheán Oíche and suggests how he came to write it. In the play I've created characters, based on those in the poem, and surrounded him with them in his daily life. For instance, I've 
recreated the hag / bailiff to the court in the poem as a wise-woman / herbalist who ministers to Merriman when he takes to his bed with a fever. Needless to say, sex is openly discussed in this play. In fact, Éabha, the noblewoman, inspired by Aoibheall, the Fairy Queen in the poem, encourages Merriman to write about the characters who surround him rather than about nature.

MP: Regarding your use of the animal trope, one is immediately attracted to the recurrence of human-animal hybrids, as in your poems of selkies and mermaids, for instance. Could you please tell us about the way you have negotiated the traditional or legendary dimension and the modern construction of female subjectivity in these motifs of human-animal hybridity?

CdF: Although some of my poems are peopled by selkies, mermaids and flying women, the feeling of the hybrid creature who moves between worlds may occur as a result of being an inbetween person myself. From the time I was a small child I've been moving back and forth across the Border on the small island of Ireland, from one jurisdiction to another. I suspect that this ongoing movement permeates my work and may give an underlying feel of having a foot in different camps. This is certainly true when it comes to moving between languages.

For example, in the poem "Seal dá saol: A time in her life" I have taken a story, that of the seal-woman who assumes human form, and given it a different slant. In the original story the seal-woman is presented as being trapped in this world, on land, unable to return to her own world, the sea, because the fisherman who has fallen in love with her has hidden her cloak and prevented her from doing so. I have overturned this scenario in that in my poem it is the sealwoman who hides her own cloak. I have empowered her so that she can come and go as she pleases. I often read this poem at gigs as it also works as a metaphor for moving between languages.

Apart from giving voice to male characters in my plays, most of my work is written from a woman's viewpoint. Just as I empowered the seal-woman in question, and the imramundertaking heroine, I have also empowered women in the Monsanto sequence, written during a residency in Portugal, in cuir amach seo dom: riddle me this.

MP: By the way, in that "Monsanto" section in cuir amach seo dom: riddle me this there is an animal protagonist, a lizard, that accompanies, inspires (but also eludes) you through that sequence of poems. Could you comment on the significance of this lizard's presence in those poems?

CdF: I read in translation The Book of Chameleons by José Eduardo Agualusa, which is narrated by a lizard. The lizard lives with Félix Ventura, a black albino who sells past histories to people. When I was staying in Monsanto I was on my own, apart from a lizard who came in and out of the kitchen. He reminded me of the lizard at the back of my son's house in Sardinia and I couldn't resist the nod to Agualusa, using the lizard as trope. Had he been a mouse the story would have been different.

I also liked the idea of creating and selling "back stories", something which we all do to an extent, whether aware of it or not, and may have employed this device in some of the poems in the Monsanto sequence.

While residencies tend to be beneficial in that they remove the writer from everyday responsibilities and demands, and provide a different, sometimes exotic, location which can be inspirational, the fact remains that relocating to a new and strange place can be lonely. In Monsanto I was on my own in a tiny village on top of a hill. The people I met, the restauranteur, the shopkeeper and the tourist guide, all left in the evening. The lizard who would come into the kitchen was my only constant companion. 
As well as acting as companion and providing inspiration and a hook in which to couch these poems, he also, thankfully, eluded me from time to time. Principally, he helped root me to the place. He had been there first, as had the cow in the folktale-inspired "An Bhó Dheireanach: The Last Cow" and the imagined slaves who had built the Roman Road in "An Bóthar Rómhánach: The Roman Road". Women from a local village who set up a temporary bakery in a disused hut in "Obair na mBan: Women's Work" were part of an Easter tradition that stretched back centuries. As my sojourn in Monsanto coincided with Easter, people travelled to the village to attend religious services. Never was I more glad to become one of the congregation at Midnight Mass.

MP: The title of your recent collection, I bhFreagairt ar Rilke: In response to Rilke, suggests a dialogue with Rainer Maria Rilke, a writer who, like you, crossed national and linguistic barriers. Rilke's poetry excels in his tropes and motifs from the natural world. What is the source of your attraction for this writer?

CdF: I became attracted to Rilke's French oeuvre during a residency in the Centre Culturel Irlandais in Paris in the autumn of 2011. I am by no means an expert in his work but feel that his four hundred plus poems in French differ in tone and style from those in German, his native language. Most of the poems in French were written during his final years in Valais, a Frenchspeaking canton in Switzerland. In I bhFreagairt ar Rilke: In Response to Rilke I respond to Migration des Forces (Rilke).

My attraction to Rilke happened. I didn't seek him out. During the days in which I settled in the Centre Culturel Irlandais, his name kept popping up as described in the poem "Aithním Anois Thú / Now I Recognise You":

$$
\begin{aligned}
& \text { Your name - Rainer Maria Rilke - } \\
& \text { can be heard on the Rue Touillier }
\end{aligned}
$$

and on Rue de l'Abbé de l'Épée -

streets where you lived -

in the Musée de Cluny, Musée Rodin -

places where you left your trace. (De Freine, Rilke 32)

It was as though he had visited before me all the places I frequented. His presence could be described as a haunting which I came to accept and which I explore in I bhFreagairt ar Rilke: In Response to Rilke. This book contains thirty-three poems, eight of which were composed to form a narrative in which I address Rilke directly. The other twenty- five, each of which is preceded by an epigraph, respond to poems in Migration des Forces (one fifth of the complete book which I actually responded to in full!). There are many of the familiar tropes to be found in this work: flowers, mirror images, angels, people at windows, entertainers, inspired no doubt, by his sojourns in Paris and by the beautiful countryside in Valais. Poems in I bhFreagairt ar Rilke: In Response to Rilke include titles such as "Geranium / Géiréiniam", "Rose / Rós", "Lily / Lile". One short poem "Ár nDeora / Our Tears", set in the Jardin des Plantes, a short walk 
from the Centre Culturel Irlandais, addresses climate change. Its epigraph is: "The Angels love our tears / Les Anges aiment nos pleurs":

the trees and plants dazzle us

with their beauty.

The scent of danger makes us weep

for their future. (De Fréine, Rilke 4)

The final poem, "Thar n-Ais i gConamara / Back in Connemara" (De Fréine, Rilke 78) - the only one not set in Paris, (in which I refer to Connemara as home!) - suggests that, not only does the haunting continue, but that my hydrangeas have turned blue, referencing one of Rilke's German poems "Blaue Hortensie: Blue Hydrangea".

LMGA: In 2020, the world went through the devastating experience of Covid-19. Literature, in particular, came to the fore to help people endure lockdown, isolation and fear, while writers were urged to record this social and health crisis. As a conclusion to this interview, we would like to ask you how this experience has affected, and indeed may still be affecting, your creative work.

CdF: Although the bulk of I bhFreagairt ar Rilke: In Response to Rilke was written in 2011, and two poetic sequences were composed during my time in America (Autumn 2013), I wrote no poetry during the years 2014-2019. This was because my time was taken up with the plays, biography and thriller.

In fact, I had taken such a long break from poetry, I worried I might never return to it in the insecure way that writers often doubt themselves. However, just before lockdown, I came across The Flame, the final book of poetry by Leonard Cohen and, in reading it, began to write poems in response to some of his many powerful images. This opened a "poetic portal" and led me to jot down notes about the pandemic during the early days in which I was cocooned. When the Arts Council announced its "Covid-19 Response Award" I decided to apply. The receipt of the award has culminated in a sequence of bilingual poetry and short prose pieces "In Search of a Horizon: Léaslíne á Lorg”. The iniative was to encourage work that would be presented online and this is what I intend doing during the coming months, though I do not preclude the publication of the work in print form at a later stage.

The opening poem "Comhairle / Advice" describes an imagined encounter with Ceres, Goddess of Agriculture, in which she advises that the time has come to return to the field of poetry "wherever it was to be found in this urban sprawl". While some of the poems explore personal preoccupations, others take a look at what is going on outside Ireland and on how the pandemic is impacting other people and events. One poem considers the plight of the Navajo whose per capita losses due to the virus are the highest in the US; another concerns the Olympic Torch, now being held for a year in Tokyo and compares its status to the journey of the Olympic Torch to Beijing in 2008 during which the poet Shi Tao was being held in prison.

I also explore the positive outcomes of the pandemic in that, along with many others (according to interviews and news reports), I take the time to look at our attitude to lifestyle, the environment, our carbon footprint and the way in which nature, in the guise of fox and birdsong, reclaimed Dublin's deserted shopping streets. One of the poems and one of the prose pieces hark back to Fiacha Fola suggesting parallels, between Covid-19 and Hepatitis C. 
However, the underlying theme of the sequence asks: where do we go from here? Whatever the answer to that might be, there is no doubt that the future of our family will be enriched by the arrival of Eva, our beautiful granddaughter, born during the pandemic.

\section{Notes}

${ }^{1}$ We wish to acknowledge the grant PGC2018-093545-B-I00 MCIU / AEI / FEDER, UE for the research project "The Animal Trope", and the funded research project PID2019-109565RB-I00 on "Illness in the Age of Extinction".

\section{Works Cited}

Agualusa, José Eduardo. The Book of Chameleons. London: Arcadia Books, 2006.

Cohen, Leonard. The Flame. Edinburgh: Canongate Books Ltd, 2018.

De Fréine, Celia. Faoi Chabáistí is Ríonacha. An Spidéal, Co. Galway: Cló Iar-Chonnacht, 2001.

. “Ocras”. Faoi Chabáistí is Ríonacha. Indreabhán: Cló Iar-Chonnacht, 2001. 13. Translated as "Hunger". Scarecrows at Newtownards. Dublin: Scotus Press, 2005. 55. "Seal dá saol". Faoi Chabáistí is Ríonacha. Indreabhán: Cló Iar-Chonnacht, 2001.

71. Translated as "A time in her life". Scarecrows at Newtownards. Dublin: Scotus Press, 2005. 72.

. Fiacha Fola. An Spidéal, Co. Galway: Cló Iar-Chonnacht, 2004. . Scarecrows at Newtownards. Dublin: Scotus Press, 2005.

. Lorg: Quest. Film-poem. Dir. Biju Viswanath. 2007. 16 June 2020. https://vimeo.com/71731670.

. Seal: Sojourn. Film-poem. Dir. Biju Viswanath. 9 February 2019. 16 June 2020. https://www.youtube.com/watch?v=v5fY_6VkNko. . Mná Dána. Dublin: Arlen House, 2009. . “Cóirín na dTonn”. Mná Dána. Dublin: Arlen House, 2009. 77-158.

. "Casadh", in Gach Áit Eile. Rehearsed reading. Peacock Theatre. Abbey Theatre production. 2009. . imram: odyssey. Dublin: Arlen House, 2010. . Aibitir Aoise: Alphabet of an Age. Dublin: Arlen House, 2011. "Boladh an Mhismín Fhiáin: The Scent of Wild Mint". Aibítir Aoise : Alphabet of an Age. Dublin: Arlen House, 2011. 20-21.

. "Lorg: Quest". Aibítir Aoise: Alphabet of an Age. Dublin: Arlen House, 2011. 6871.

. "Seal: Sojourn". Aibitir Aoise: Alphabet of an Age. Dublin: Arlen House, 2011. 9295.

. Present. Rehearsed reading. Pavilion Theatre. Pavilion Playwrights 8x10, 2012.

Brian Merriman's The Midnight Court. Dublin: Arlen House, 2012.

. Cruachás: Plight. Dublin: Arlen House. 2013.

. Meanmarc: Desire. Dublin: Arlen House. 2013.

"Na Deoraithe". Blúiriní, by Celia de Fréine and Fidelma Ní Ghallchobhair. Dublin: COGG. 2013. 5-13. . cuir amach seo dom: riddle me this. Dublin: Arlen House, 2014.

"An Bhean Uasal is an tAonadharcach: The Lady and the Unicorn". cuir amach seo dom: riddle me this. Dublin: Arlen House, 2014. 70-85.

"An Bhó Dheireanach: The Last Cow". cuir amach seo dom: riddle me this. Dublin: Arlen House, 2014. 90-91. 
. "An Bóthar Rómhánach: The Roman Road". cuir amach seo dom: riddle me this.

Dublin: Arlen House, 2014. 98-99.

. "Obair na mBan: Women's Work". cuir amach seo dom: riddle me this. Dublin:

Arlen House, 2014. 96-97.

. A Lesson in Can't. Dublin: Scotus Press, 2014.

Blood Debts. Dublin: Scotus Press, 2014.

Seamstress. Umbrella Theatre Company. National Gallery of Ireland, part of an 8x10

production, 2014, 2015. Seamstress renamed Beth, produced as part of Katie \& Beth

(Katie by Lia Mills), Two Cities One Book Festival; Dalkey Book Festival; Maureen

O'Hara Studio, Mill Theatre, 2016.

. Safe. Umbrella Theatre Company. Maureen O'Hara Studio. Mill Theatre, 2015.

. Luíse. Umbrella Theatre Company. Scoil Bhríde Ranelagh. 2016, 2017 (Ranelagh

Arts Festival); (IMRAM Féile Litríochta Gaeilge / Irish Language Literature Festival, 2017).

. "Doth Suffer a Sea-Change". Migrant Shores. Irish, Moroccan \& Galician Poetry.

Ed. Manuela Palacios. Cliffs of Moher: Salmon Poetry, 2017. 100-101.

. "On the Bull Wall", in Eight of Hearts. Umbrella Theatre Company. Players TCD.

2015; Theatre \&36. 2018.

Luíse Ghabhánach Ní Dhufaigh. Ceannródaí. Dublin: LeabhairCOMHAR, 2018.

Shortlisted for Love Leabhar Gaeilge Award; An Post Irish Book Awards 2018. Winner of ACIS Leabhar Taighde na Bliana, 2019.

. Cur i gCéill. Dublin: LeabhairCOMHAR, 2019.

. I bhFreagairt ar Rilke: In response to Rilke. Dublin: Arlen House, 2020.

. "Comhairle / Advice", "Léaslíne á Lorg: In Search of a Horizon”. Forthcoming.

De Fréine, Celia and Fidelma Ní Ghallchobhair. Blúiríní. Dublin: COGG. 2013.

Gleeson, Sinéad. Constellations. London: Picador, 2019.

McKee, Mark Gerard and Celia de Fréine. Threshold. Visual and poetic installation. MS17 Art Project. 2017. 16 June 2020. https://ms17artproject.com/threshold-mark-gerard-mckeecelia-de-freine/

Merriman, Brian. The Midnight Court / Cúirt an Mheán Oíche. Ed. Brian O'Conchubhair. Syracuse, N.Y.: Syracuse University Press, 2011.

Mills, Lia. In Your Face. Dublin: Penguin Ireland, 2007.

Rilke, Rainer Maria. Migration des Forces. In The Complete French Poems. Poulin. J. R. Jr. (Translator). Minneapolis: Graywolf Press, 2002.

Wade, Jennifer. "Census 2011: 1.77m Say They Are Able to Speak Irish". The Journal.ie. 29 March 2011. 16 June 2020. https://www.thejournal.ie/census-2011-1-77m-say-theyare-able-to-speak-irish-400442-Mar2012/

Williams, Tennessee. The Rose Tattoo. New York: New Directions Publishing, 2010 (1951).

Received: 20 June $2020 \quad$ Revised version accepted: 7 September 2020

Manuela Palacios-González is Senior Lecturer of English at the University of Santiago de Compostela in Spain. She has directed five research projects on contemporary Irish and Galician literature that have been funded by the Spanish Ministry of Science, and has edited and co-edited several books in relation to this topic: Pluriversos (2003), Palabras extremas (2008), Writing Bonds (2009), Creation, Publishing and Criticism (2010), To the Winds Our Sails (2010), Forked Tongues (2012), Six Galician Poets (2016), Migrant Shores (2017) and Estudios Irlandeses, Special Issue 15.2, 2020, pp.102-116. ISSN 1699-311X. Manuela Palacios-González and Luz Mar González-Arias. 


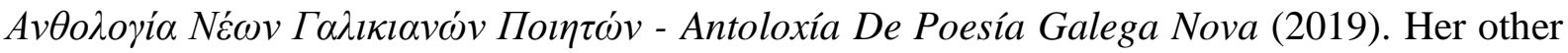
publications include translations of European and Arabic poetry and fiction, a monograph on Virginia Woolf's pictorial imagery, Shakespeare's Richard III, and articles on ecocriticism.

manuela.palacios@usc.es

Luz Mar González-Arias is Senior Lecturer in the English Department, University of Oviedo. Her research is primarily in the areas of body theory and Medical Humanities, as applied to the work of contemporary Irish women poets. Recent publications include her essay on PTSD "Impossible Returns: The Trope of the Soldier in Celia de Fréine's Poetry" (Irish University Review, 2018); her contribution to Animals in Irish Literature and Culture (Palgrave, 2015) "“A pedigree bitch, like myself”: (Non)Human Illness and Death in Dorothy Molloy's Poetry'; and "Ageing Iconography: Non-normative Representations of the Irish Maternal Bodies" (The Nordic Irish Studies Journal, 2018). She is the editor of National Identities and Imperfections in Contemporary Irish Literature (Palgrave, 2017), and is currently working on a book-length monograph on Dorothy Molloy. In 2016 and 2017 González-Arias curated Amanda Coogan at the Niemeyer Centre (Avilés, Asturias).

luzmar@uniovi.es 